\title{
STRATEGI PENINGKATAN ADOPSI INOVASI PADA PETERNAKAN SAPI PERAH RAKYAT DI DAERAH ISTIMEWA YOGYAKARTA, JAWA TENGAH, DAN JAWA TIMUR
}

\section{STRATEGIES FOR INCREASING ADOPTION INNOVATION OF SMALLHOLDER DAIRY FARMS IN YOGYAKARTA SPECIAL REGION, CENTRAL AND EAST JAVA PROVINCES}

\author{
Septi Nur Wulan Mulatmi*, Budi Guntoro, Budi Prasetyo Widyobroto, Sudi Nurtini, dan \\ Ambar Pertiwiningrum \\ Fakultas Peternakan, Universitas Gadjah Mada, Yogyakarta, 55281
}

Submitted: 1 August 2016, Accepted: 13 October 2016

\section{INTISARI}

Penelitian ini bertujuan untuk merumuskan strategi peningkatan adopsi inovasi pada peternakan sapi perah rakyat. Penelitian dilakukan pada Bulan Mei hingga Juli 2015. Penelitian dilakukan dengan metode survei. Pemilihan responden dilakukan dengan metode multi stage sampling yaitu sebanyak 270 peternak sapi perah rakyat di Provinsi Daerah Istimewa Yogyakarta, Jawa Tengah, dan Jawa Timur. Metode yang digunakan adalah deskriptif kualitatif dengan menggunakan analisis SWOT (strength, weakness, opportunity and threat). Hasil penelitian merumuskan strategi peningkatan adopsi inovasi antara lain mengoptimalkan sumber daya; memberikan informasi yang jelas dan kontinyu mengenai inovasi; mempermudah akses informasi dengan memperbanyak penyebaran informasi; memberikan program pendampingan, penyuluhan, dan pelatihan disertai demonstrasi mengenai inovasi; meningkatkan partisipasi peternak; memperkuat kelembagaan peternak; mengusahakan alat pendukung inovasi secara bersama-sama; meningkatkan kualitas penyuluh, media, dan cara penyampaian informasi; mengoptimalkan bantuan pemerintah dan lembaga swadaya masyarakat.

(Kata kunci: Adopsi inovasi, Peternakan sapi perah rakyat, Strategi)

\section{ABSTRACT}

This study was aimed to formulate strategies for increasing adoption innovation in the smallholder dairy farms. The study was conducted in May to July 2015. The research was conducted using survey method. The selection of respondents was conducted using multi-stage sampling to 270 dairy smallholder farmers in Yogyakarta Region, Central, and East Java Provinces. The method used was descriptive qualitative by using SWOT analysis (strength, weakness, opportunity and threat). The results of the research which is to optimize resources; provide a clear and continuous information about innovation; facilitate access to information by extending the dissemination of information; provide mentoring programs, counseling, and training with a demonstration of the innovation; increase the participation of dairy farmers; strengthen institutional dairy farmers; seek a tool to support innovation together; improve the quality of extension, media, and the delivery of information; and optimize government and NGO aid.

(Key words: Adoption of innovation, Strategy, The smallholder dairy farmer)

\footnotetext{
* Korespondensi (corresponding author):

Telp. +62 85643720872

E-mail: septi.mulatmi@gmail.com
} 


\section{Pendahuluan}

Inovasi adalah gagasan, tindakan atau barang yang dianggap baru oleh seseorang. Kebaruan inovasi itu diukur secara subyektif, menurut pandangan individu yang menangkapnya. Rogers (2003) menyatakan bahwa proses adopsi itu terjadi mulai seseorang mendengar suatu ide baru sampai akhirnya ia melaksanakannya (mengadopsinya).

Strategi didefinisikan sebagai suatu pendekatan yang diperlukan dalam perencanaan dan pelaksanaan suatu kegiatan. David (2002) menyatakan strategi merupakan cara untuk mencapai sasaran jangka panjang untuk mencapai tujuan usaha, program tindak lanjut serta prioritas alokasi sumber daya. Rangkuti (2013) menyatakan bahwa analisis SWOT adalah intensifikasi berbagai faktor secara sistematis untuk merumuskan strategi. Analisis ini didasarkan pada logika yang dapat memaksimalkan kekuatan (strengths) dan peluang (opportunities), namun secara bersamaan dapat meminimalkan kelemahan (weaknesses) dan ancaman (threats).

Kemajuan usaha peternakan sapi perah harus didukung dengan teknologi yang tepat sehingga secara maksimal mampu meningkatkan produksi, akan tetapi dalam praktek peternakan sapi perah saat ini tidak sepenuhnya memahami penggunaan teknologi tersebut. Pengetahuan tradisional sangat penting untuk pengamanan pangan dan sistem pertanian jangka panjang, namun inovasi dan pengetahuan modern perlu dimanfaatkan dan disinergikan dengan pengetahuan lokal yang merupakan aset dalam rangka membangun pertanian yang berkelanjutan, karena pada dasarnya kedua pengetahuan itu komplementer.

Pemeliharaan sapi perah pada peternak rakyat masih menggunakan teknologi yang bersifat sederhana dan berdasarkan pengalaman. Adopsi inovasi merupakan suatu upaya meningkatkan produktivitas usaha, karena dengan adopsi inovasi diharapkan akan meningkatkan kualitas dan kuantitas produk yang kemudian juga akan memberikan efek terhadap pendapatan dan kemajuan usaha. Demikian juga pada usaha sapi perah, peternak harus dapat melakukan adopsi inovasi yang secara empiris dapat meningkatkan produktivitas ternak. Strategi peningkatan adopsi inovasi yang tepat diperlukan guna memaksimalkan kekuatan dan peluang serta meminimalkan kelemahan dan ancaman yang ada pada peternakan sapi perah rakyat, sehingga tujuan peternakan sapi perah dapat dicapai Tujuan penelitian ini adalah untuk merumuskan strategi peningkatan adopsi inovasi peternakan sapi perah rakyat.

\section{Materi dan Metode}

Materi penelitian adalah 270 peternak sapi perah rakyat di DIY, Jawa Tengah, dan Jawa Timur. Penelitian dilakukan pada bulan Mei sampai Juli 2015. Penelitian dilakukan dengan menggunakan metode survei. Pemilihan ketiga provinsi sebagai lokasi penelitian dikarenakan termasuk dalam provinsi dengan populasi sapi perah tertinggi di Indonesia. Metode penelitian yang digunakan adalah deskriptif analitis. Data dikumpulkan dengan menggunakan metode wawancara, observasi, dan pencatatan terkait dengan aktivitas adopsi inovasi pada peternakan sapi perah rakyat. Penentuan sampel dilakukan dengan metode Multi-stage sampling yaitu dipilih 90 peternak sapi perah rakyat di masing-masing provinsi. Faktor internal dan eksternal yang dipertimbangkan terkait dengan strategi peningkatan adopsi inovasi di peternakan sapi perah rakyat. Penentuan alternatif strategi yang sesuai bagi peternakan sapi perah adalah dengan cara membuat SWOT matrik. SWOT matrik ini dibangun berdasarkan hasil analisis faktor-faktor strategis baik eksternal maupun internal yang terdiri dari fokus peluang, ancaman, kekuatan dan kelemahan (Rangkuti, 2013).

\section{Hasil dan Pembahasan}

\section{Karakteristik responden}

Umur peternak sapi perah rakyat di DIY, Jawa Tengah dan Jawa Timur berkisar antara 15 sampai 85 tahun (Tabel 1). Rerata umur peternak sapi perah rakyat di DIY, Jawa Tengah, dan Jawa Timur adalah 47,43 tahun. Usia produktif adalah kisaran umur 15 sampai 65 tahun (BPS, 2015). Umur peternak sapi perah rakyat di ketiga provinsi tergolong dalam usia produktif, sehingga dalam pengembangan kemampuan dan ketrampilan masih sangat dimungkinkan. Rerata pendidikan formal yang dijalani oleh peternak sapi perah rakyat di DIY, Jawa Tengah, dan Jawa Timur adalah 6 tahun atau Sekolah Dasar. Hal ini mengindikasikan 
bahwa rerata peternak sapi perah rakyat di ketiga provinsi masih mengenyam pendidikan rendah. Rerata pendidikan nonformal yang dijalani oleh peternak sapi perah rakyat di DIY, Jawa Tengah, dan Jawa Timur adalah 1 kali. Peternak di tiga provinsi masih kurang mendapat informasi, pengetahuan, dan pelatihan dalam

Tabel 1. Karakteristik peternak sapi perah rakyat (characteristics of dairy smallholder farmers)

\begin{tabular}{|c|c|c|}
\hline Parameter & Jumlah (number of farmers) & $\%$ \\
\hline \multicolumn{3}{|l|}{ Umur (tahun) (age (year)) } \\
\hline $15-25$ & 5 & 1,85 \\
\hline $26-35$ & 44 & 16,30 \\
\hline $36-45$ & 76 & 28,15 \\
\hline $46-55$ & 82 & 30,37 \\
\hline $56-65$ & 49 & 18,15 \\
\hline $66-75$ & 11 & 4,07 \\
\hline $76-85$ & 3 & 1,11 \\
\hline Rerata (average) & & $47,43 \pm 12,05$ \\
\hline \multicolumn{3}{|c|}{ Pendidikan formal (tahun) (formal education (year)) } \\
\hline Tidak sekolah (no schooling) & 37 & 13,70 \\
\hline SD (elementary school) & 146 & 54,07 \\
\hline SMP (junior high school) & 37 & 13,70 \\
\hline SMA ( high school) & 45 & 16,67 \\
\hline Perguruan tinggi (college/university) & 5 & 1,85 \\
\hline \multicolumn{3}{|c|}{ Pendidikan nonformal (jumlah) (informal education) } \\
\hline 0 & 46 & 65,18 \\
\hline 1 & 29 & 24,07 \\
\hline 2 & 6 & 5,18 \\
\hline 3 & 7 & 4,44 \\
\hline$>3$ & 2 & 1,11 \\
\hline \multicolumn{3}{|c|}{ Pengalaman beternak (tahun) (farming experience (year)) } \\
\hline $1-5$ & 36 & 13,33 \\
\hline $6-10$ & 42 & 15,56 \\
\hline $11-15$ & 47 & 17,41 \\
\hline $16-20$ & 54 & 20.00 \\
\hline $21-25$ & 36 & 13,33 \\
\hline$>25$ & 55 & 20,37 \\
\hline Rerata (average) & & $18,59 \pm 10,75$ \\
\hline \multicolumn{3}{|c|}{ Kepemilikan ternak (UT) (number of cattle owned (AU)) } \\
\hline $0,01-4$ & 132 & 48,89 \\
\hline $4,01-8$ & 95 & 35,19 \\
\hline $8,01-12$ & 27 & 10.00 \\
\hline $12,01-16$ & 6 & 2,22 \\
\hline $16,01-20$ & 4 & 1,48 \\
\hline$>20$ & 6 & 2,22 \\
\hline Rerata (average) & & $5,56 \pm 4,99$ \\
\hline \multicolumn{3}{|c|}{ Jumlah anggota Keluarga (orang) (number of family members) } \\
\hline $0-1$ & 5 & 1,85 \\
\hline $2-3$ & 114 & 42,22 \\
\hline $4-5$ & 126 & 46,67 \\
\hline$>5$ & 25 & 9,26 \\
\hline
\end{tabular}


pemeliharaan sapi perah. Rerata pengalaman beternak sapi perah di DIY, Jawa Tengah, dan Jawa Timur adalah 18,59 tahun. Peternak sapi perah rakyat di DIY, Jawa tengah, dan Jawa Timur memiliki cukup pengalaman dalam usaha ternak sapi perah. Rerata kepemilikan ternak sapi perah ketiga wilayah adalah 5,56 UT dan rerata jumlah anggota keluarga peternak sapi perah rakyat sebanyak 2 orang.

Rogers (2003) menyatakan bahwa faktor internal yang mempengaruhi adopsi inovasi adalah karakteristik peternak, meliputi umur, tingkat pendidikan, jumlah tanggungan keluarga, intensitas penyuluhan yang diterima, serta keberanian mengambil resiko. Faktor-faktor karakteristik pengguna inovasi meliputi tingkat pendidikan, pengalaman, skala usaha, dan produktifitas merupakan faktor penting dalam proses adopsi inovasi di pedesaan (Rangkuti, 2009).

\section{Adopsi inovasi di DIY, Jawa Tengah, dan Jawa Timur}

Jenis inovasi yang dikenal di ketiga provinsi adalah jerami amoniasi, jerami fermentasi, pakan konsentrat, complete feed, lumbung pakan ternak, pemilihan benih rumput unggul, IB, pemilihan bibit ternak unggul, biogas, pembuatan kompos, recording, teknik perkandangan yang baik, mesin perah, dan mesin chopper. IB merupakan inovasi yang paling banyak diadopsi oleh peternak, dan inovasi yang paling sedikit diadopsi oleh peternak adalah pengolahan pakan yaitu jerami amoniasi (Tabel 2). Inseminasi buatan (IB) atau kawin suntik adalah upaya memasukkan semen/mani ke dalam saluran reproduksi hewan betina yang sedang birahi dengan bantuan inseminator agar hewan bunting (Herawati et al., 2012). Persentase adopsi IB tinggi karena peternak menilai bahwa biaya IB lebih murah daripada biaya pemeliharaan pejantan, selain itu tingkat keberhasilannya juga lebih tinggi dibandingkan dengan kawin alami. Sebagian besar peternak belum melakukan adopsi inovasi mengenai pengolahan pakan berbahan dasar jerami karena sebagian peternak merasa bahwa pengolahan jerami fermentasi dan amoniasi memerlukan banyak tenaga, waktu, dan tempat, sedangkan ternak sudah mau makan hanya dengan jerami saja.

Informasi mengenai inovasi yang sering diterima peternak berasal dari beberapa sumber antara lain dinas pertanian, penyuluh, kelompok ternak, peternak lain, keluarga, maupun media massa. Informasi mengenai inovasi yang ada pada peternakan sapi perah cukup banyak sumbernya. Jelas atau tidaknya informasi mengenai inovasi yang disampaikan oleh sumber informasi akan berpengaruh terhadap pengetahuan peternak yang kemudian berpengaruh terhadap minat peternak untuk melakukan adopsi inovasi. Soekartawi (2005) menyebutkan bahwa sumber informasi sangat berpengaruh dalam proses adopsi. Kecepatan adopsi yang

Tabel 2. Adopsi Inovasi di tingkat peternak sapi perah rakyat (innovations were addopted by dairy farmers)

\begin{tabular}{lcr}
\hline \hline \multicolumn{1}{c}{ Macam inovasi (kinds of innovations) } & Jumlah (number of farmers) & $(\%)$ \\
\hline Jerami amoniasi (ammoniated rice straw) & 21 & 7,78 \\
Jerami fermentasi (fermented rice straw) & 86 & 31,85 \\
Pakan konsentrat (feed concentrates) & 261 & 96,67 \\
Pakan jadi (complete feed) & 22 & 8,15 \\
Lumbung pakan ternak (barns fodder) & 53 & 19,63 \\
Pemilihan benih unggul (selection of seeds sown pastures) & 70 & 25,93 \\
Inseminasi buatan (artificial insemination) & 263 & 97,41 \\
Pemilihan bibit ternak unggul (selection of seed eminent & 80 & 29,63 \\
livestock) & 194 & 71,85 \\
Biogas & 86 & 31,85 \\
Pembuatan kompos (compost) & 79 & 29,26 \\
Pencatatan (recording) & 72 & 26,67 \\
Teknik perkandangan yang baik (good stall system) & 120 & 44,44 \\
Mesin perah (milking machine) & 134 & 49,63 \\
Mesin chopper (chopper machine) & &
\end{tabular}


dilakukan seseorang pada tiap tahapan adopsi sangat dipengaruhi oleh ragam sumber informasi yang menyampaikan suatu inovasi (Mardikanto, 1993 cit. Sari et al. 2009). Hal tersebut menunjukkan bahwa dengan beragamnya sumber informasi yang dimanfaatkan calon adopter sebelum mengadopsi inovasi akan berpengaruh terhadap adopsi terhadap suatu inovasi. Keberagaman sumber informasi yang dimanfaatkan menunjukkan bahwa seseorang mengetahui tentang suatu inovasi dari berbagai macam sumber yang mana sumber-sumber informasi tersebut dapat memberikan informasi yang saling menguatkan atau melengkapi terhadap suatu inovasi.

Banyak metode yang dilakukan untuk menyampaikan informasi kepada peternak antara lain pelatihan, kunjungan, pertemuan kelompok, dan demonstrasi. Berdasarkan penelitian yang telah dilakukan diketahui bahwa peternak pada umumnya mengakses saluran komunikasi berupa saluran interpersonal seperti penyuluhan peternakan maupun perkumpulan kelompok ternak. Kegiatan penyuluhan maupun perkumpulan kelompok ternak merupakan kegiatan yang baik untuk dilakukan, karena dari penyuluhan maupun perkumpulan kelompok ternak dapat diperoleh informasi yang akan bermanfaat untuk kemajuan usaha peternakan. Media yang digunakan untuk menyampaikan informasi mengenai inovasi sudah banyak ditemukan, salah satunya melalui media massa. Prajarto (2004) menyatakan bahwa media massa berperan dalam perbesaran multikulturalisme dalam masyarakat. Media massa yang dapat dimanfaatkan peternak berupa leaflet, bulletin, maupun majalah. Semakin sering peternak berinteraksi dengan sumber informasi, maka pengetahuan peternak tersebut akan semakin tinggi.

\section{Kendala}

Kendala yang sering dihadapi mengenai adopsi inovasi berkaitan dengan berbagai hal, diantaranya kurangnya akses dengan sumber informasi. Pelaksanaan penyuluhan, menunjukkan bahwa penyuluh melakukan kegiatan penyuluhan tergantung pada kegiatan projek pemerintah dengan fasilitas pendukung seadanya (Lestari dan Machya, 2010). Beberapa lokasi penelitian menunjukkan belum adanya Opinion Leader pada kelompok ternak. Sebagian besar peternak yang mengikuti penyuluhan adalah peternak yang menjadi pengurus kelompok atau koperasi, dan informasi yang diperoleh jarang disampaikan secara terperinci kepada peternak lainnya. Opinion leader adalah suatu kelompok atau orang lain, sebagai orang yang mempunyai suatu keahlian dan pengetahuan dan juga dipertimbangkan sebagai sumber yang layak untuk informasi dan nasihat (Bertrandias dan Goldsmith, 2006). Pengetahuan dan informasi pada masyarakat pedesaan didapatkan dari pemimpin yang mereka anggap sebagai 'Opinion leaders', sehingga pemimpin merupakan orang yang paling penting dalam sirkulasi pesan dan informasi (Darmastuti dan Prasela, 2010).

Kendala lain yang dihadapi adalah akses informasi yang masih sulit. Beberapa peternak akan mencari informasi sendiri dengan cara bertanya pada para ahli, membaca media cetak atau mencari informasi melalui internet. Para ahli yang mengetahui mengenai inovasi jarang ditemui oleh peternak, hanya sesekali pada saat perkumpulan kelompok ternak atau koperasi. Ahli mengenai inovasi dapat berasal dari pengurus koperasi, penyuluh, lembaga pemerintahan, LSM, dan perguruan tinggi. Sebagai penyuluh dan pemberi informasi pada peternak, faktor bahasa dan cara berkomunikasi sangat perlu diperhatikan. Setiap daerah memiliki bahasa sendiri dan tidak sedikit peternak yang masih sulit menggunakan dan mengerti Bahasa Indonesia. Para penyuluh diharapkan dapat menguasai bahasa daerah yang digunakan oleh peternak dengan baik sehingga lebih mudah dalam menyampaikan informasi dan dimengerti oleh para peternak. Selain itu, karakter setiap peternak berbeda, proses penyampaian informasi harus secara jelas, sederhana dan menarik bagi para peternak.

Informasi yang bersumber pada media cetak juga jarang untuk sampai ke peternak rakyat. Apabila media cetak bisa sampai ke peternak, masih ada peternak yang buta huruf sehingga sulit juga memperoleh informasi. Sumber informasi berupa media cetak lebih baik apabila dibuat dengan bahasa yang sederhana dan menggunakan ilustrasi berupa gambar yang menarik dan mudah dimengerti. Selain itu, meskipun informasi mengenai inovasi peternakan sapi perah sudah banyak ditemukan, sebagian besar disampaikan melalui internet. Peternak 
sapi perah rakyat umumnya bukan pengguna gadget, sehingga hanya sebagian kecil saja yang bisa mengakses informasi melalui internet. Internet belum terlalu banyak dimengerti oleh peternak rakyat, sehingga penyuluhan mengenai pengenalan internet dapat terlebih dahulu harus dilakukan.

\section{Faktor internal dan ekstenal peternakan sapi perah}

Ada tiga hal yang diharapkan oleh suatu aktivitas ekonomi yaitu sesuatu yang ingin dicapai, apa masalah yang dihadapi (faktor internal), dan peluang (faktor eksternal) yang dihadapi dalam mencapai keinginan tersebut. Dengan melakukan auditing kepada dua faktor internal dan eksternal akan dapat merumuskan strategi dan tindakan yang harus dilakukan. Faktor internal penentu strategi peningkatan adopsi inovasi meliputi berbagai macam faktor yang menggambarkan potensi dan keadaan peternakan. Faktor internal berupa Kekuatan (Strengths) yaitu : 1) Pengalaman beternak cukup lama, 2) Peternak masih di usia produktif, 3) Populasi ternak yang terus meningkat, 4) Pakan melimpah di musim hujan, 5) Limbah melimpah, 6) Semen mudah diperoleh. Faktor internal berupa Kelemahan (Weakness) yaitu 1) Pendidikan rendah, 2) Kesulitan pakan di musim kemarau, 3) Kepemilikan ternak sedikit, 4) Keikutsertaan dalam pelatihan dan penyuluhan sedikit, 5) Informasi mengenai inovasi sedikit, 6) Kesulitan mengakses informasi mengenai inovasi, 7) Produksi susu rendah, 8) Keterbatasan modal, 9) Cara beternak masih tradisional.

Faktor eksternal penentu strategi peningkatan adopsi inovasi meliputi berbagai macam faktor yang menggambarkan keadaan atau kondisi luar yang berpengaruh terhadap peningkatan adopsi inovasi peternakan sapi perah. Faktor eksternal berupa Peluang (Opportunities) yaitu :1) Permintaan susu tinggi, 2) Peran koperasi susu, 3) Banyak inovasi di bidang peternakan, 4) Informasi inovasi mudah dicari di internet atau media massa, 5) Bantuan pemerintah dan LSM, sedangkan faktor eksternal yang berupa Ancaman (Threats): 1) Harga pakan tidak stabil, 2) Inovasi sulit dicoba, 3) Harga inovasi seperti mesin perah dan chopper mahal, 4) Kualitas penyuluh dan cara penyampaian informasi.

$$
\text { Penyusunan alternatif strategi }
$$
peningkatan adopsi inovasi dilakukan dengan menggunakan alat bantu matrik SWOT. Alternatif matriks SWOT terdiri dari 4 macam, yaitu strategi SO, WO, ST, dan WT. Perumusan alternatif strategi dipertimbangkan berdasarkan identifikasi faktor internal dan eksternal, serta pengaruh dan homogenitas yang berada pada lokasi penelitian. Kombinasi dan perpaduan antara faktor internal dan eksternal tersebut akan dapat diperoleh beberapa alternatif strategi yang dapat diterapkan dalam adopsi inovasi pada usaha peternakan sapi perah rakyat di DIY, Jawa Tengah dan Jawa Timur. (Tabel 3) Secara rinci, ada empat tipe alternatif strategi yang dapat diterapkan dalam dalam adopsi inovasi pada usaha peternakan sapi perah rakyat di DIY, Jawa Tengah dan Jawa Timur yaitu SO, WO, ST, dan WT.

Strategi SO atau strategi kekuatan peluang merupakan strategi yang menggunakan kekuatan internal untuk dapat memanfaatkan peluang eksternal. Alternatif strategi SO yang dapat dirumuskan adalah 1) mengoptimalkan sumber daya yang dimiliki peternak untuk pengembangan usaha peternakan sapi perah; 2) memberikan informasi yang jelas dan secara kontinyu mengenai inovasi yang ada di peternakan sapi perah; 3) mengoptimalkan bantuan pemerintah dan LSM dalam hal inovasi yang dapat mendukung pengembangan usaha. Teknologi untuk para peternak harus menggunakan sumberdaya yang sudah dimiliki, jika mutlak memerlukan sumberdaya dari luar maka harus dipastikan bahwa sumberdaya tersebut murah dan dapat diperoleh secara teratur dengan mudah (Bunch, 2001). Sonbait (2011) menyatakan bahwa alternatif strategi yang dapat mendukung adopsi inovasi salah satunya adalah dengan melakukan penyuluhan secara kontinyu dengan memanfaatkan komunikasi efektif.

Strategi WO atau strategi kelemahan peluang merupakan strategi untuk dapat meminimalkan kelemahan yang ada untuk dapat memanfaatkan suatu peluang eksternal. Alternatif strategi yang dapat dirumuskan meliputi: 1) memberikan program pendampingan dan penyuluhan sehingga dapat meningkatkan pengetahuan dan ketrampilan peternak; 2) meningkatkan partisipasi peternak dalam kelompok atau koperasi; 3) memberikan penyuluhan dan pelatihan mengenai inovasi; 4) mempermudah akses informasi mengenai inovasi dengan cara memperbanyak 
penyebaran informasi melalui media cetak maupun elektronik. Abdullah (2008) menyatakan bahwa partisipasi peternak sangat menentukan diseminasi teknologi, peternak harus terlibat dalam keseluruhan aspek pengembangan usahaternak dan dikembangkan berdasarkan inisiatif peternak, dan peternak harus memiliki responsifitas terhadap pengembangan teknologi.

Strategi ST atau strategi kekuatan ancaman merupakan strategi untuk dapat mengoptimalkan kekuatan internal yang dimiliki dalam menghindari ancaman. Alternatif strategi ST yang dapat dirumuskan antara lain: 1) mengembangkan keterampilan sumber daya manusia sehingga dapat meningkatkan produktivitas; 2) memberikan penyuluhan yang disertai dengan demonstrasi agar peternak dapat melihat secara langsung hasil inovasi yang diperkenalkan. Kompleksitas suatu inovasi mempunyaipengaruh yang besar terhadap kecepatan adopsi inovasi, apabila suatu inovasi sulit penyampaiannya dapat dibantu dengan melakukan peragaan, demonstrasi dan pelatihan secara partisipatif (Musyafak dan Ibrahim, 2005). Sonbait (2011) menyatakan bahwa alternatif strategi yang dapat mendukung adopsi inovasi adalah dengan pembinaan dan bimbingan secara intensif dari dinas peternakan untuk meningkatkan keterampilan peternak melalui penyuluhan dan pelatihan.

Strategi WT atau strategi kelemahan ancaman merupakan strategi defensif untuk meminimalkan kelemahan internal dan

Tabel 3. Matrik perumusan strategi peningkatan adopsi inovasi (matrix formulation of a strategy to increase the adoption of innovation)




menghindari ancaman eksternal. Alternatif strategi yang dapat dirumuskan antara lain adalah: 1) memperkuat kelembagaan peternak sehingga peternak memiliki akses informasi yang mudah mengenai inovasi; 2) mengusahakan instalasi atau mesin yang mendukung inovasi secara bersama-sama, sehingga tidak membebani peternak secara finansial; 3) meningkatkan kualitas penyuluh, media, dan cara penyampaian informasi sesuai dengan kebutuhan dan kemampuan peternak dalam menerima informasi. Abdullah (2008) menyatakan bahwa untuk meningkatkan ketepatan adopsi peternak terhadap tekhnologi, maka perlu dilakukan upaya melalui peningkatan intensitas dan kualitas penyuluhan dengan metode, teknik, dan media yang sesuai dengan kondisi peternak.

\section{Kesimpulan}

Strategi peningkatan adopsi inovasi antara lain mengoptimalkan sumber daya baik modal manusia yang berasal dari diri peternak maupun eksternal seperti ternak yang dimiliki, lingkungan, serta pemerintah; memberikan informasi yang jelas dan kontinyu mengenai inovasi; mempermudah akses informasi dengan memperbanyak penyebaran informasi; memberikan program pendampingan, penyuluhan, dan pelatihan disertai demonstrasi mengenai inovasi; meningkatkan partisipasi peternak; memperkuat kelembagaan peternak; mengusahakan alat pendukung inovasi secara bersama-sama; meningkatkan kualitas penyuluh, media, dan cara penyampaian informasi; serta mengoptimalkan bantuan pemerintah dan LSM.

\section{Ucapan Terima Kasih}

Penelitian ini didanai oleh Direktorat Pendidikan Tinggi, Kementerian Riset, Teknologi dan Pendidikan Tinggi, Republik Indonesia (melalui Hibah PUPT 2015), dan Universitas Gadjah Mada.

\section{Daftar Pustaka}

Abdullah. 2008. Ketepatan Adopsi Inovasi Peternak Terhadap Teknologi Fermentasi Jerami Padi di Kabupaten Bulukumba. Jurusan Sosial Ekonomi Peternakan, Fakultas Peternakan, Universitas Hasanuddin.
Bertrandias, L. and R. E. Goldsmith, 2006. Some psychological motivations for fashion opinion leadership and fashion opinion seeking, Journal of Fashion Marketing and Management 10: 25-40.

BPS. 2015. https://www.bps.go.id/index. php/istilah/index? Istilah_page=4. Diakses pada 15 Januari 2016.

Bunch, R. 2001. Pedoman Pengembangan Pertanian Berpangkal pada Rakyat. Edisi kedua. Yayasan Obor Indonesia, Jakarta.

Darmastuti, R. dan M. K. Prasela. 2010. Two ways communication: Sebuah model pembelajaran dalam komunitas samin di Sukolilo Pati. Jurnal IImu Komunikasi 8: 204-216.

David, F. R. 2002. Manajemen Strategis : Konsep. PT Prenhallindo, Jakarta.

Herawati T, Anneke Anggraeni, Lisa Praharani, Dwi Utami, dan Argi Argiris. 2012. Peran inseminator dalam keberhasilan inseminasi buatan pada sapi perah. Balai PenelitianTernak, Ciawi. Bogor.

Lestari, P. dan Machya. 2010. Model komunikasi dalam sosialisasi pengarusutaman gender dan anggaran di Provinsi Daerah Istimewa Yogyakarta. Jurnal IImu Komunikasi 8: 191-203.

Musyafak, A. dan Ibrahim, T. M. 2005. Strategi percepatan adopsi dan difusi inovasi pertanian mendukung Prima Tani. Analisis Kebijakan Pertanian 1: 20-37.

Prajarto, N. 2004. Komunikasi multikultural dalam perspektif HAM. Jurnal IImu Komunikasi 2 Nomor 2, Mei-Agustus 2004.

Rangkuti, F. 2013. Analisis SWOT Teknik Membedah Kasus Bisnis. Gramedia Pustaka, Jakarta.

Rangkuti, P. A. 2009. Analisis Peran Jaringan Komunikasi Petani dalam Adopsi inovasi Traktor Tangan di Kabupaten Cianjur Jawa Barat. Jurnal Agro Ekonomi 27: 45-60.

Rogers, E. 2003. Difussion of Innovations. Fifth Edition. Free Press. New York, London, Toronto, Sidney.

Sari, A. I., S. P. Syahlani, dan F. T. Haryadi. 2009. Karakteristik kategori adopter dalam adopsi inovasi feed additive herbal untuk ayam pedaging. Buletin Peternakan 33: 196-203. 
Soekartawi. 2005. Prinsip Dasar Komunikasi

Pertanian. Universitas Indonesia

Press, Jakarta.
Sonbait, L. Y. 2011. Identifikasi Problem Komunikasi Peternak di Kabupaten Manokwari Papua Barat. Jurusan Produksi Ternak. Fakultas Peternakan Perikanan dan IImu Kelautan, Universitas Negeri Papua, Papua. 